\title{
Z BADAŃ WYKOPALISKOWYCH I INWENTARYZACYJNYCH W NOWYM KRAKOWIE, GM. DARLOWO, STAN. 1
}

\author{
ARCHAEOLOGICAL AND CATALOGUING STUDIES AT NOWY KRAKÓW, \\ DARŁOWO COMMUNE, SITE 1
}

\author{
Ignacy Skrzypek \\ Muzeum w Koszalinie \\ ul. Marszałka J. Piłsudskiego 53, 75-502 Koszalin, Poland
}

ABSTRACT. The article presents history of hitherto conducing studies at this site. It is also aimed at presentation of a short-lived excavation of the early Roman Iron Age burial mound as well as the Hallstatt settlement features, conducted in the 1991 season.

Po przeszło 45 latach od ukazania się drukiem opracowania dokumentacji z badań niemieckich w 1937 r. na kurhanie z okresu wpływów rzymskich ${ }^{1}$ w Nowym Krakowie, powracamy jeszcze raz do tego ciekawego stanowiska, na którym w roku 1991 zostały przeprowadzone prace wykopaliskowe oraz inwentaryzacyjne ${ }^{2}$.

Stanowisko znane jest w literaturze archeologicznej pod nazwą Nowy Kraków, chociaż położone jest niedaleko wsi Przystawy (ryc. 1). Znajduje się bowiem na terenie lasów państwowych należących niegdyś do Nadleśnictwa Nowy Kraków, a obecnie do Nadleśnictwa w Sławnie, i stąd taka jego pierwotna lokalizacja. Nie zawsze to jednak było klarowne i nawet archeolodzy niemieccy umiejscawiali znaleziska $\mathrm{z}$ tego kurhanu pod miejscowością Przystawy ${ }^{3}$. Te rozbieżności występowały później również w polskiej literaturze archeologicznej ${ }^{4}$.

Cmentarzysko kurhanowe odkryte zostało przypadkowo w 1926 r. przez robotników leśnych, którzy wybierając glinę do budowy drogi z nasypu jednego z pagórków (kurhanów) natrafili na pięknie ornamentowane, czarne naczynie z wczesnego okresu rzymskiego, zaliczone później do grupy V według R. Schindlera ${ }^{5}$ (ryc. 2). Naczynie przy

\footnotetext{
${ }^{1}$ Garczýnski 1956.

${ }^{2}$ Informator 1997.

${ }^{3}$ Ku nkel 1939, s. 51 (rycina), przyp. 80, s. 59; por. archiwum działu archeologicznego Muzcum w Koszalinie, t. $412 / \mathrm{S}$.

${ }^{4}$ Walenta 1981 , s. 155, nr 234 , s. 148 , nr 187.

${ }^{5}$ Schindler 1940, s. 163, Karte 2.
} 


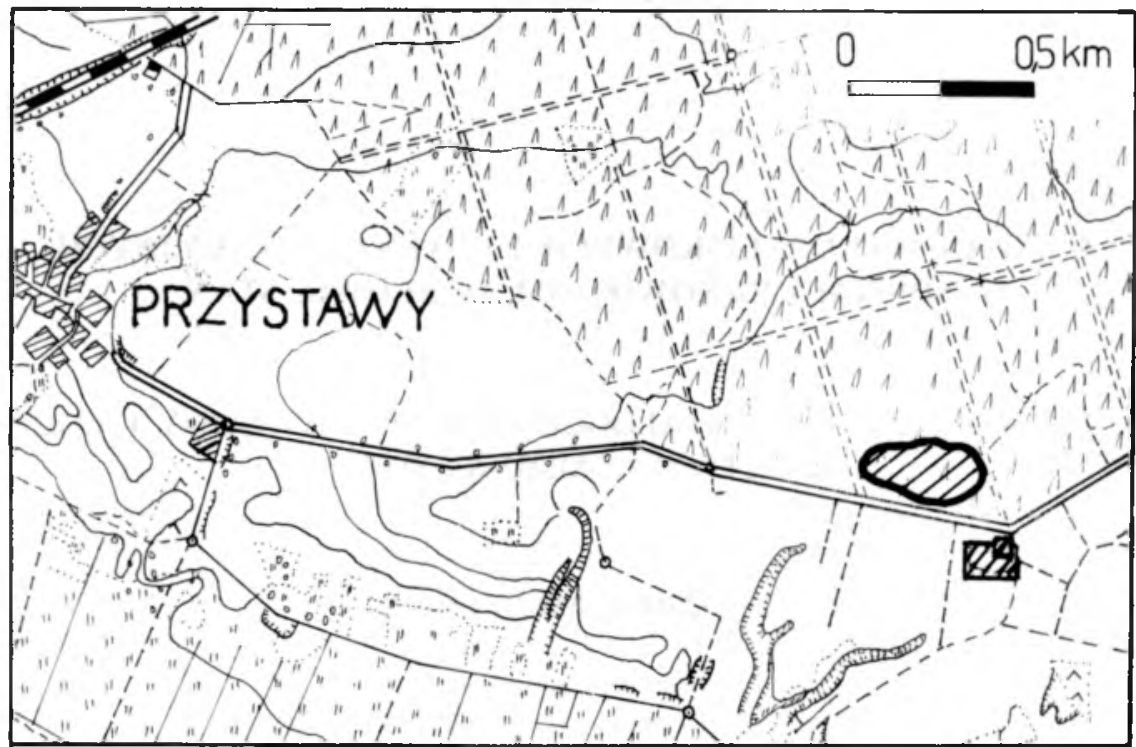

22 - zasięg występowania kurhanów

Ryc. 1. Nowy Kraków, gm. Darłowo, stan. 1. Lokalizacja cmentarzyska kurhanowego Abb. 1. Nowy Kraków, Gem. Darłowo, Fst. 1. Lage des Hügelgräberfeldes

wydobywaniu uległo rozbiciu, jednak przekazane do ówczesnego Muzeum Regionalnego w Darłowie (Heimatmuseum Rügenwalde), zostało wyklejone, zrekonstruowane i zainwentaryzowane pod nr. MD 299. Obecnie ta piękna situla grupy V według R. Wołagiewicza ${ }^{6}$ znajduje się już od 1970 r. w zbiorach archeologicznych Muzeum w Koszalinie, zainwentaryzowana pod nr MK/9468 ${ }^{7}$. Jest to naczynie o wysmuklej dolnej części korpusu, z wysoko umieszczoną największą wydętością brzuśca i skośnie na zewnątrz ściętą krawędzią wylewu. U nasady szyjki znajduje się wąska listwa, a ornament składa się ze swastyki oraz schodkowo meandrujących poczwórnych linii zygzakowatych. Dokładne wymiary naczynia: wysokość - $28,5 \mathrm{~cm}$, średnica wylewu $19,5 \mathrm{~cm}$, średnica brzuśca - 28,5 cm, średnica dna - 13,5 cm (ryc. 2). W literaturze czasami identyfikowane jest ono błędnie, jako pochodzące $z$ kurhanu w Przystawach ${ }^{8}$. Tymczasem chodzi o to samo stanowisko, prawidłowo lokalizowane w Nowym Krakowie, gmina Darłowo, stan. 1, arkusz AZP 12-23, nr stanowiska na obszarze $138^{9}$.

\footnotetext{
${ }^{6}$ Wołagiewicz 1993, s. 167 , tabl. $64: 1$.

${ }^{7}$ Muzeum w Koszalinie, archiwum działu archeologicznego, t. MK/1070/S. Według W. Garczyńskiego naczynie mialo znajdować się w Römisch-Germanisches Zentralmuseum w Mainz (Garczyński 1956, s. 119 , przyp. 4).

${ }^{8}$ Walenta 1981 , s. 155 .

${ }^{9}$ Muzeum w Koszalinie, dział archeologiczny, archiwum „Archeologicznego Zdjęcia Polski", t. MK/268.
} 


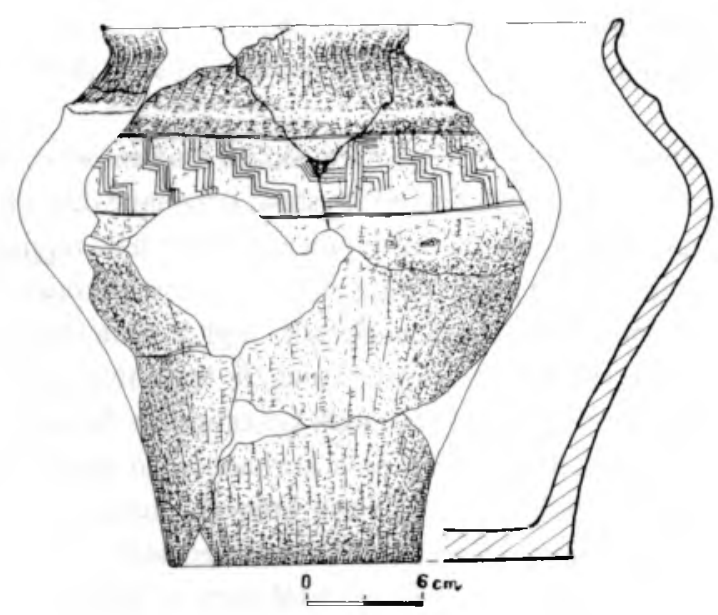

Ryc. 2. Nowy Kraków, gm. Darłowo, stan. 1. Naczynie grupy V znalezione w kurhanie w 1926 r., obecnie w Muzeum w Koszalinie

Abb. 2. Nowy Kraków, Gem. Darłowo, Fst. 1. Gefäß der Gruppe V, gefunden in einem Hügel im Jahr 1926, jetzt in Museum Koszalin

W roku 1937 ówczesny powiatowy opiekun zabytków archeologicznych na powiat Sławno, mjr Dieter von Kleist, zlokalizował miejsce, skąd pochodziło to atrakcyjne naczynie. Okazało się, że był to kurhan położony na południowym skraju Lasów Państwowych Nowy Kraków, oddział leśny nr 13, przy drodze z Przystaw do Gorzycy (ryc. 1). Stwierdził on, że kurhan częściowo był rozkopany, a w jego sąsiedztwie rozpoznał jeszcze co najmniej 10 innych tego typu obiektów, które zaliczył do V-VI okresu epoki brązu $^{10}$. Jeszcze w tym samym roku, w dniach 13-15 października, archeolog Hans-Jürgen Eggers z Muzeum Krajowego w Szczecinie (Pommersche Landesmuseum), rozkopał zachodnią część kurhanu' '. Kopał on rowami na krzyż, miejscami zwężając przekopy $\mathrm{z}$ powodu trudności w eksploracji nasypu zbudowanego ze zbitej gliny.

Ziemia na nasyp pochodziła prawdopodobnie $z$ rowu otaczającego kurhan. $U$ podstawy obiektu natrafiono na przemieszaną czarną ziemię $z$ węglami drzewnymi, paleniska (?) - również z ułamkami naczyń i kośćmi na warstwie przepalonej gliny, oraz jamy grobowe. H. J. Eggers ustalił chronologię kurhanu na okres wczesnorzymski oraz stwierdził, że pochówkiem, dla którego zbudowany został nasyp, był usytuowany centralnie grób $\mathrm{nr} 8$ $\mathrm{z}$ resztkami stosu, $\mathrm{z}$ którego pochodzić miało naczynie odkryte $\mathrm{w} 1926 \mathrm{r}$. Pozostałe groby były płaskie, wcześniejsze od kurhanu. $Z$ ośmiu odkrytych w sumie pochówków grób $\mathrm{nr} 7$ pochodził z młodszej epoki brązu, grób $\mathrm{nr} 3$, skrzynkowy, zbudowany z łupanych kamieni, należy przypisać ludności kultury pomorskiej, grób nr 8 należy do starszej fazy

\footnotetext{
${ }^{10} \mathrm{~K} 1$ e ist 1955 , s. 30, Neu-Krakow nr 546 i 547, Taf. 24:2.

" Teczka archiwalna Muzeum Narodowego w Szczecinie, nr 1291.
} 
kultury wielbarskiej, natomiast pozostałe obiekty należy łączyć z okresem halsztackim ${ }^{12}$. Penetrując okolice badanego obiektu H.J. Eggers zarejestrowal prawdopodobnie 33 dalsze kurhany.

Inspiracją do zainteresowania się cmentarzyskiem kurhanowym w 1991 r. było pisemne zgłoszenie Tomasza Różańskiego z Przystaw, przesłane do ówczesnego Muzeum Okręgowego w Koszalinie, o prowadzonych pracach leśnych na terenie obiektów archeologicznych. Pracownicy działu archeologicznego i pracowni konserwatorskiej w osobach: mgr Ignacy Skrzypek, mgr Krystyna Hahula, mgr Jolanta Ilkiewicz i mgr Tomasz Wojciechowski, 13 maja $1991 \mathrm{r}$. wykonali inspekcję terenową pola kurhanowego potożonego wówczas na terenie gm. Darłowo, woj. koszalińskie. Na miejscu okazało się, że na terenie południowo-zachodniej strefy pola kurhanowego prowadzono już dwa lata wcześniej wycinkę starych buków, na miejscu których posadzono młodnik sosnowy. Użycie do prac leśnych ciężkiego sprzętu mechanicznego naruszyło nasypy kilku kurhanów. W trakcie tej wizyty ustalono też właściwą lokalizację stanowiska. Zgodnie z obecnym podziałem administracyjnym, omawiane cmentarzysko kurhanowe położone jest na terenie leśnictwa Czarnolas, obręb Nowy Kraków, oddział leśny nr 180-181, Nadleśnictwo Sławno, gmina Darłowo, województwo zachodniopomorskie ${ }^{13}$.

W trakcie tej majowej penetracji archeolodzy przeprowadzili wstępne rozpoznanie kilku kwartałów leśnych. Warunki poszukiwań terenowych nie były latwe. Na obszarze zalesionym średniowiekowymi bukami i świerkami, poprzerastanym iglastym młodnikiem, tarninami, jeżynami i wysokimi paprociami, widoczność była ograniczona do kilku metrów. Pomimo to udało się wykreślić pole kurhanowe, składające się z dwóch stref występowania kurhanów: strefy północno-wschodniej porośniętej lasem świerkowo-bukowym i różnorodnymi krzewami, oraz strefy południowo-zachodniej, gdzie na miejscu starego lasu bukowego posadzono w 1989 r. młode sosny. W sumie zlokalizowano 25 kurhanów, jednak z racji utrudnionej widoczności ich liczba może zostać w przyszłości zweryfikowana (ryc. 3). Kurhan nr 1, badany przez H.J. Eggersa w 1937 r., położony w strefie północno-wschodniej, nosil jeszcze ślady dawnych wykopów. Ustalono, że na najbardziej zagrożonym obiekcie należy przeprowadzić badania ratownicze.

Celem badań, które trwały od 29 lipca do 3 sierpnia 1991 r., była weryfikacja danych archiwalnych co do chronologii obiektów i szczegółowa inwentaryzacja pola kurhanowego, niezbędna, by wpisać stanowisko do rejestru zabytków. Pracami w terenie kierowali mgr Ignacy Skrzypek i mgr Krystyna Hahuła. Sfinansowano je ze środków Państwowej Służby Ochrony Zabytków w Koszalinie i Muzeum Okręgowego w Koszalinie. Przed przystapieniem do badań wykopaliskowych sporządzono plan sytuacyjny pola kurhanowego z pomierzeniem szczegółów za pomocą zdjęcia busolowego (ryc. 3).

Kurhan wybrany do badań, oznaczony nr 2, usytuowany byl w południowo-zachodnim skupisku kurhanów, przy jego wschodniej krawędzi i należał do obiektów średniej wielkości (wymiary: średnica ok. 13 m, wysokość - ok. 12 m). Po sporządzeniu planu

\footnotetext{
2 Garczyński 1956, s. 113, przyp. 10.

${ }^{13}$ Archiwum działu archeologicznego, t. MK/1070/S.
} 


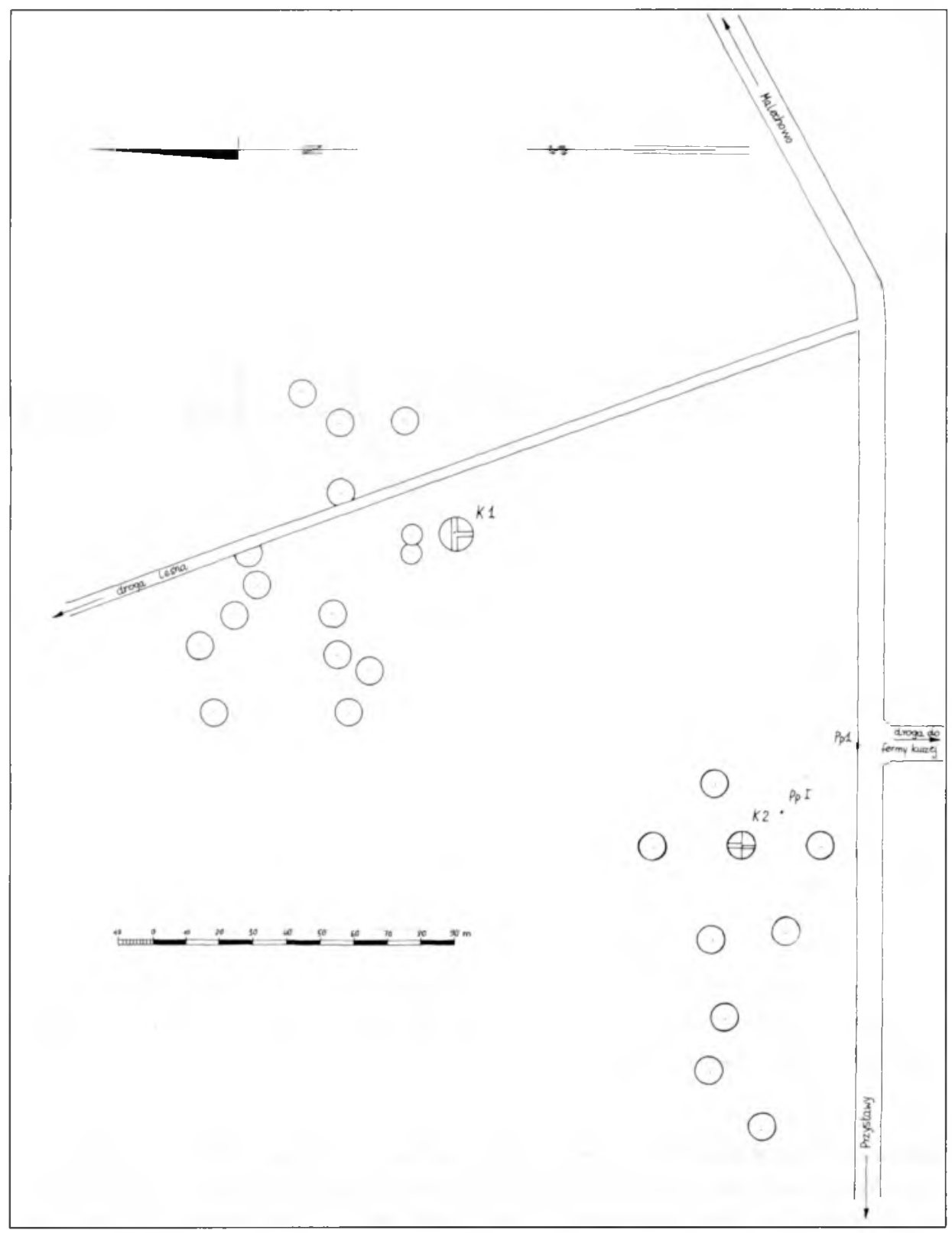

Ryc. 3. Nowy Kraków, gm. Darłowo, stan. 1. Plan sytuacyjny pola kurhanowego. Wyk. W. i T. Kosman Abb. 3. Nowy Kraków, Gem. Darłowo, Fst. 1. Situationsplan des Hügelfeldes. Ausführung W. und T. Kosman 


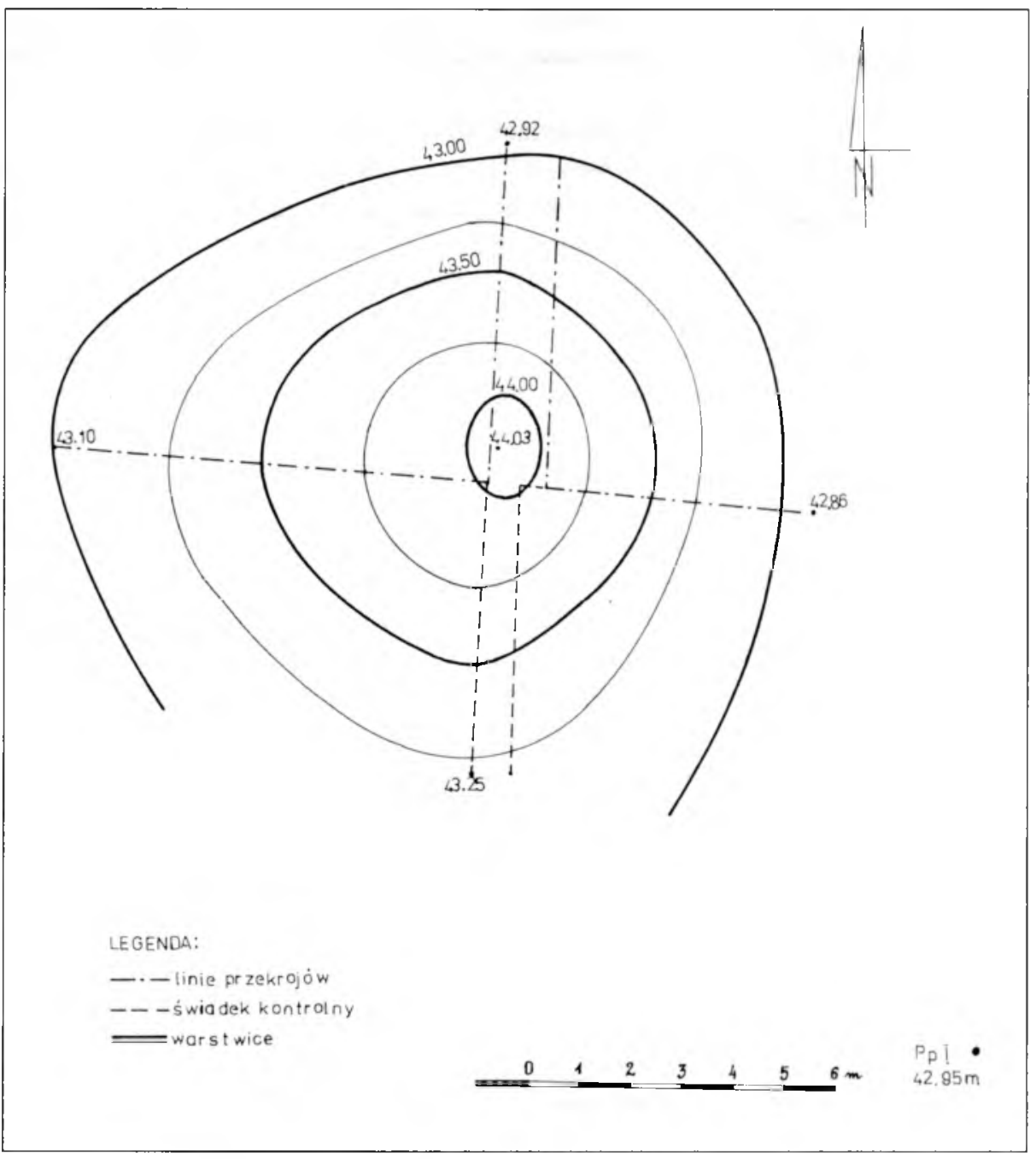

Ryc. 4. Nowy Kraków, gm. Darlowo, stan. 1. Plan sytuacyjno-wysokościowy kurhanu nr 2. Wyk. W. i T. Kosman Abb. 4. Nowy Kraków, Gem. Darłowo, Fst. 1. Höhenschichtenplan von Hügel 2. Ausführung W. und T. Kosman

warstwicowego obiektu (ryc. 4) wytyczono świadki kontrolne po liniach zbliżonych do N-S i W-E i wyeksplorowano 3/4 obiektu, pozostawiając nie zbadaną ćwiartkę północno-wschodnią (ryc. 5). Eksplorację bardzo utrudniała gliniasta struktura nasypu i jego podstawy oraz duże, rozrośnięte korzenie starych, obecnie wyciętych buków. W ćwiartkach południowych osiagnięto poziom gliny ciężkiej, oddolnie oglejonej, nie natrafiając na żaden obiekt. Jedynie przy styku świadka wschodniego i południowego odkryto skupisko ceramiki i warstwę szarej gliny z domieszką piasku. Po usunięciu świadka 
południowego przedłużono profil w kierunku północnym, eksplorując rów o szerokości $1 \mathrm{~m}$ (ryc. 5). W centrum, w warstwach nasypu, odkryto nieokreślone, bardzo mocno skorodowane przedmioty żelazne (kat. 14084) oraz 7 fragmentów naczyń (kat. 14083), wśród których wyróżniono:

a) 2 grubościenne ułamki naczyń barwy jasnobrunatnej, glinę z domieszką średnioziarnistą, grubość ścianek 0,8-0,9 cm; chronologia - okres halsztacki;

b) 3 fragmenty naczyń średniościennych barwy szarobrunatnej, w tym jeden wtórnie przepalony, grubość ścianek $0,7 \mathrm{~cm}$; chronologia - wczesny okres rzymski;

c) 2 fragmenty cienkościenne, wygładzane, barwy brunatnoceglastej, grubość ścianek $0,5 \mathrm{~cm}$; chronologia - okres halsztacki;

d) węgielki drzewne.

Warstwa szarej gliny wyraźnie wchodziła w ściany ćwiartki północno-zachodniej. Eksplorację tej ćwiartki przeprowadzono koparką do stropu szarej plamy, którą oznaczyliśmy początkowo jako obiekt A (ryc. 5). W trakcie dalszych prac plama ta, widoczna w profilach kurhanu, wypłyciła się. Podczas eksploracji stropu obiektu A zebrano 5 ułamków naczyń (kat. 14085), w tym:

a) I fragment mocno wychylonego na zewnątrz wylewu naczynia grupy $\mathrm{V}$ według R. Wołągiewicza, o krawędzi pionowo ściętej, grubość ścianek 0,7 cm (ryc. 7:1); chronologia - wczesny okres rzymski;

b) 4 fragmenty brzuśców naczyń o powierzchniach schropowaconych i gładzonych, barwy brunatnoceglastej, $\mathrm{z}$ dużą domieszką mineralną gruboziarnistą, grubość ścianek $0,8 \mathrm{~cm}$; chronologia - okres halsztacki.

Pod nasypem, na głębokości około $1 \mathrm{~m}$ od powierzchni, na poziomie calca, uchwycono zarysy dwóch obiektów. Rozległa jama nr I o wymiarach 3,60 × 1,80 (N-S), o wypełnisku gliniasto-piaszczystym, miejscami z węgielkami drzewnymi, grudkami polepy i spalenizna, o miąższości około $15 \mathrm{~cm}$, zawierala w południowej partii owalne skupisko węgli drzewnych i spalenizny z licznymi ułamkami naczyń (ryc. 6). Na jego stropie znaleziono blaszkę brązową o nieokreślonej funkcji (kat. 14 088, ryc. 7:10). W trakcie eksploracji stropu jamy zebrano ogółem 75 ułamków naczyń, z których większość jednak pochodzi z partii środkowych naczyń grubościennych, mocno schropowaconych i obrzucanych na powierzchni zewnętrznej (nr kat. 14 086). Wśród pozyskanej ceramiki wyróżniono:

a) 3 wylewy, w tym jeden poziomo uformowany, pochodzący $z$ szerokootworowego naczynia typu „kuchennego" (ryc. 7:6), drugi o krawędzi wylewu mocno wychylonej na zewnątrz (ryc. 7:2) i trzeci należący do małego naczynia beczułkowatego o zaokrąglonej krawędzi wylewu (ryc. 7:5); powierzchnia zewnętrzna schropowacona, wewnętrzna gładzona, jasnożółta i brunatna, grubość ścianek 0,8-1,2 cm; chronologia - okres halsztacki;

b) 10 fragmentów naczyń obustronnie gładzonych, cienkościennych, wśród których wyróżniono 5 wylewów naczyń baniastych, amforek i naczyń beczułkowatych (ryc. 7:3,4,7); 


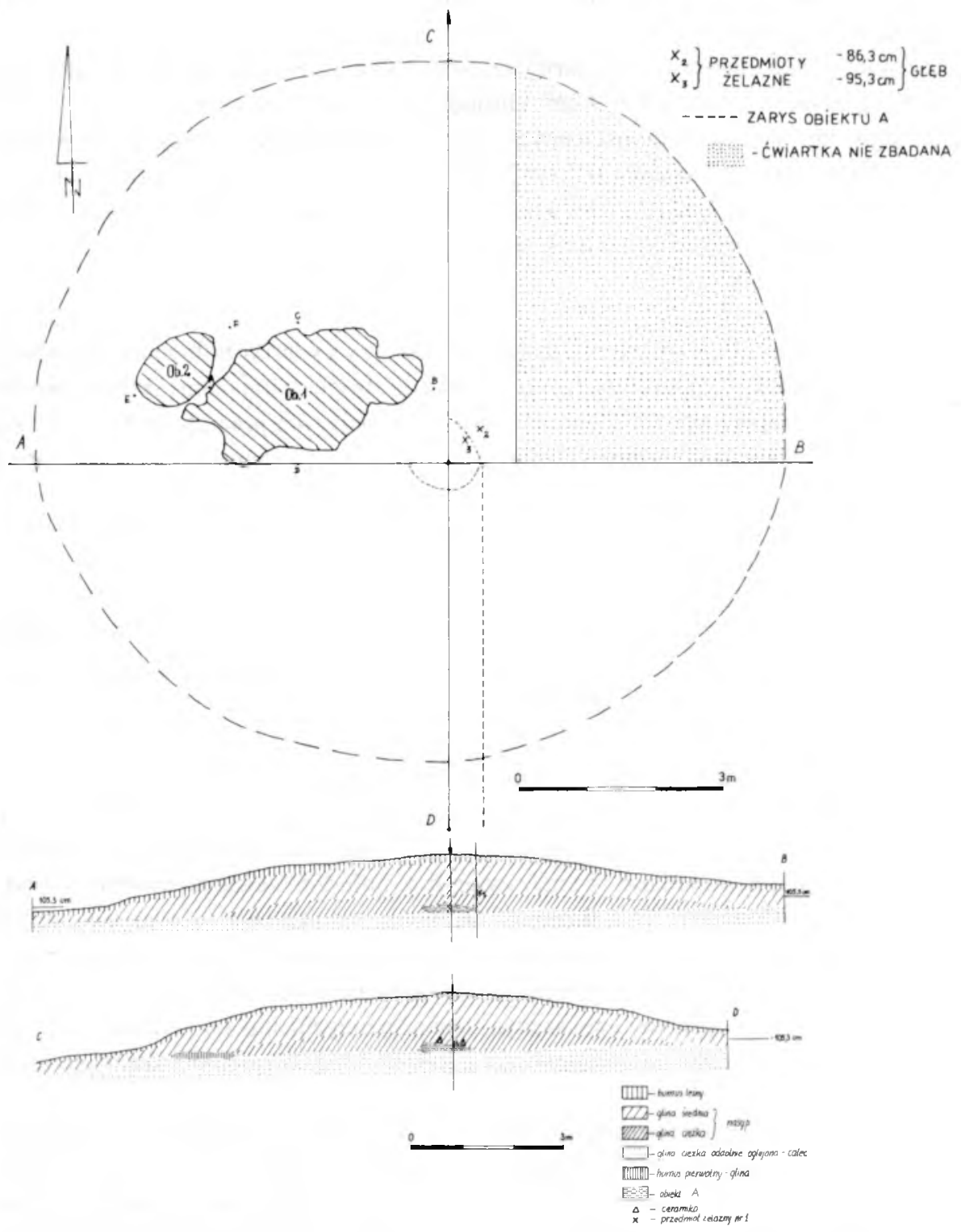

Ryc. 5. Nowy Kraków, gm. Darłowo, stan. 1. Rzut poziomy oraz profil WE i NS kurhanu nr 2 Abb. 5. Nowy Kraków, Gem. Darłowo, Fst. 1. Grundriß von Hügel 2 und West-Ost- und Nord-Süd-Profil von Hügel 2 


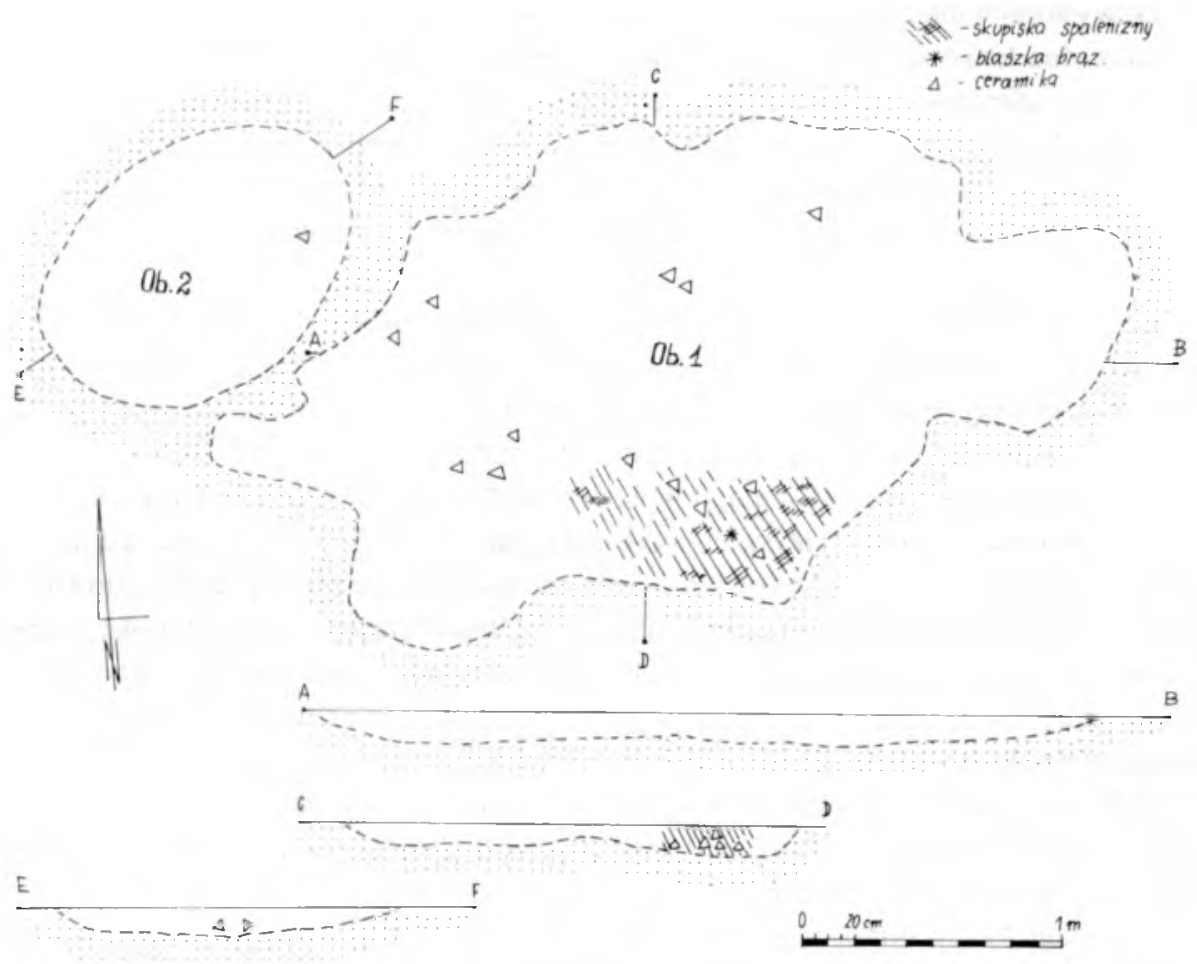

Ryc 6. Nowy Kraków, gm. Darłowo, stan. 1. Rzut poziomy i profile obiektów spod kurhanu 2

Abb. 6. Nowy Kraków, Gem. Darłowo, Fst. 1. Grundriß der Siedlungsbefunde unter Hügel 2

powierzchnia koloru ceglastego, grubość ścianek $0,4-0,6 \mathrm{~cm}$; glina wypalona słabo na kolor szarobrunatny, schudzona domieszką tłuczonego kamienia; chronologia okres halsztacki;

c) 10 fragmentów ceramiki o powierzchniach zewnętrznych szorstkich, barwy ceglastej, wewnętrznych ciemnobrunatnych.

W trakcie eksploracji zawartości jamy nr 1, w jej południowej części, uzyskano 58 fragmentów naczyń o schropowaconych i szorstkich powierzchniach zewnętrznych z okresu halsztackiego (kat. 14 088), wśród których wyróżniono:

a) 3 ułamki wylewów dużych naczyń baniastych, średniościennych, schropowaconych od samej krawędzi, mniej lub bardziej wywiniętej na zewnątrz, zdobionych niekiedy parą guzków umieszczonych tuż pod wylewem; barwa obustronnie żółtobrunatna, przełomy jednobarwne, wypał dobry; grubość ścianek 0,7-0,8 cm (ryc. 8:3-5);

b) 4 fragmenty den i partii przydennych naczyń grubościennych, bardzo silnie obrzucanych gliną na powierzchni, wypalone na kolor ceglasty; powierzchnia wewnętrzna wygładzana 
barwy żółtobrunatnej; glina schudzana dużą ilością domieszki piasku, kwarcu i miki, niektóre dna lekko wyodrębnione; grubość ścianek 1,0-1,3 cm (ryc. 8:6);

c) 1 wylew cienkościennego naczynia kształtu beczułkowatego $\mathrm{z}$ nieznacznie wyodrębnioną szyjka, krawędzią wylewu poziomo uformowanąi lekko wychyloną na zewnątrz (ryc. 8:2);

d) 1 fragment talerza krążkowatego o zaokraglonej i pogrubionej krawędzi, barwy szarej; glina z domieszką kwarcu i miki, powierzchnia szorstka, grubość - $1,0 \mathrm{~cm}$ (ryc. 8:1).

Pozostałe ułamki pochodzą z partii środkowych naczyń grubościennych, silnie schropowaconych na zewnątrz, barwy żółtobrunatnej, stanowiących zawsze podstawowy materiał ceramiczny osad ludności kultury pomorskiej, charakterystyczny dla tzw. fazy łużycko-pomorskiej okresu halsztackiego ${ }^{14}$. Występujące w naszym materiale naczynia baniaste, schropowacone od samego wylewu, zaopatrzone niekiedy w guzki, wywodzą się bez wątpienia z tradycji łużyckich wczesnej epoki żelaza. W kulturze pomorskiej można podać liczne przykłady ich występowania na osadach i cmentarzyskach, datowanych ogólnie na Hallstatt D i wczesny okres lateński ${ }^{15}$. Ułamki ceramiki tzw. stołowej, cienkościennej i gładzonej, są mniej liczne, ale również stanowią typowy asortyment osadowy, mniej czuły na zmiany w czasie, występujący w kulturze lużyckiej i pomorskiej, od młodszej epoki brązu po schyłkową fazę okresu halsztackiego ${ }^{16}$. Talerze krążkowate, których jeden egzemplarz znalazł się w naszym materiale, wywodzą się także z zasobów ceramicznych kultury łużyckiej i licznie występują na osadach kultury pomorskiej u schyłku Hallstatt D aż do środkowego okresu lateńskiego ${ }^{17}$.

Obiekt $\mathrm{nr} 2$ o owalnym zarysie i wymiarach $1,70 \times 0,80 \mathrm{~m}$ wystapił w bezpośrednim sąsiedztwie obiektu nr 1, od jego strony zachodniej (ryc. 7). Zawartość stanowiła szarobrązowa gliniasta ziemia z zawartością ceramiki i grudkami polepy. Ten typowo osadowy obiekt posiadał niewielką miąższość dochodzącą do około $0,10 \mathrm{~m}$ (ryc. 7, E-F). Pozyskano z niego 15 drobnych ułamków naczyń o powierzchniach zewnętrznych szorstkich i schropowaconych, w tym 1 wylew małego naczynia beczułkowatego (ryc. 7:9) oraz 1 fragment brzuśca obrzucanego gliną z widocznymi ciągami palcowymi (kat. 14 089). Chronologia - ogólnie okres halsztacki.

Oba obiekty są pozostałością osady ludności kultury pomorskiej z okresu halsztackiego, na co wskazują liczne i różnorodne ułamki naczyń, które wystąiły w ich wypełniskach. $Z$ uwagi na brak konkretnych zabytków specjalnych trudno określić ich funkcję. Określenie charakteru jam często natrafia na spore trudności. W dotychczasowej praktyce kryterium klasyfikacji odsłanianych obiektów stanowił rodzaj inwentarza, kształt negatywów w poziomie i pionie oraz rozmiary. Jednak nawet po uwzględnieniu tego schematu kwestia określenia funkcjonalnego jam 1 i 2 nie jest sprawą jednoznaczną ${ }^{18}$.

\footnotetext{
${ }^{14}$ Skrzypek 1987 , s. 45 , przyp. 10.

${ }^{15}$ Strzyżewski, Żurawski 1973, s. 98 , ryc. $4: 2,6,10$; Skrzy pek 1982, s. 17 i 24, przyp. 8; 1998 , s. 228 , ryc. $17: \mathrm{c}$, d.

${ }^{16}$ Kostrzewski 1966 , s. 52-91.

${ }^{17}$ Skrzypek 1998, s. 26; 1976, s. 94, przyp. 16 i 17.

${ }^{18}$ Skrzypek 1987, s. 37, przyp. 2 i 3; Cnotliwy, Kamiński, Rogosz 1975, s. 77-79.
} 


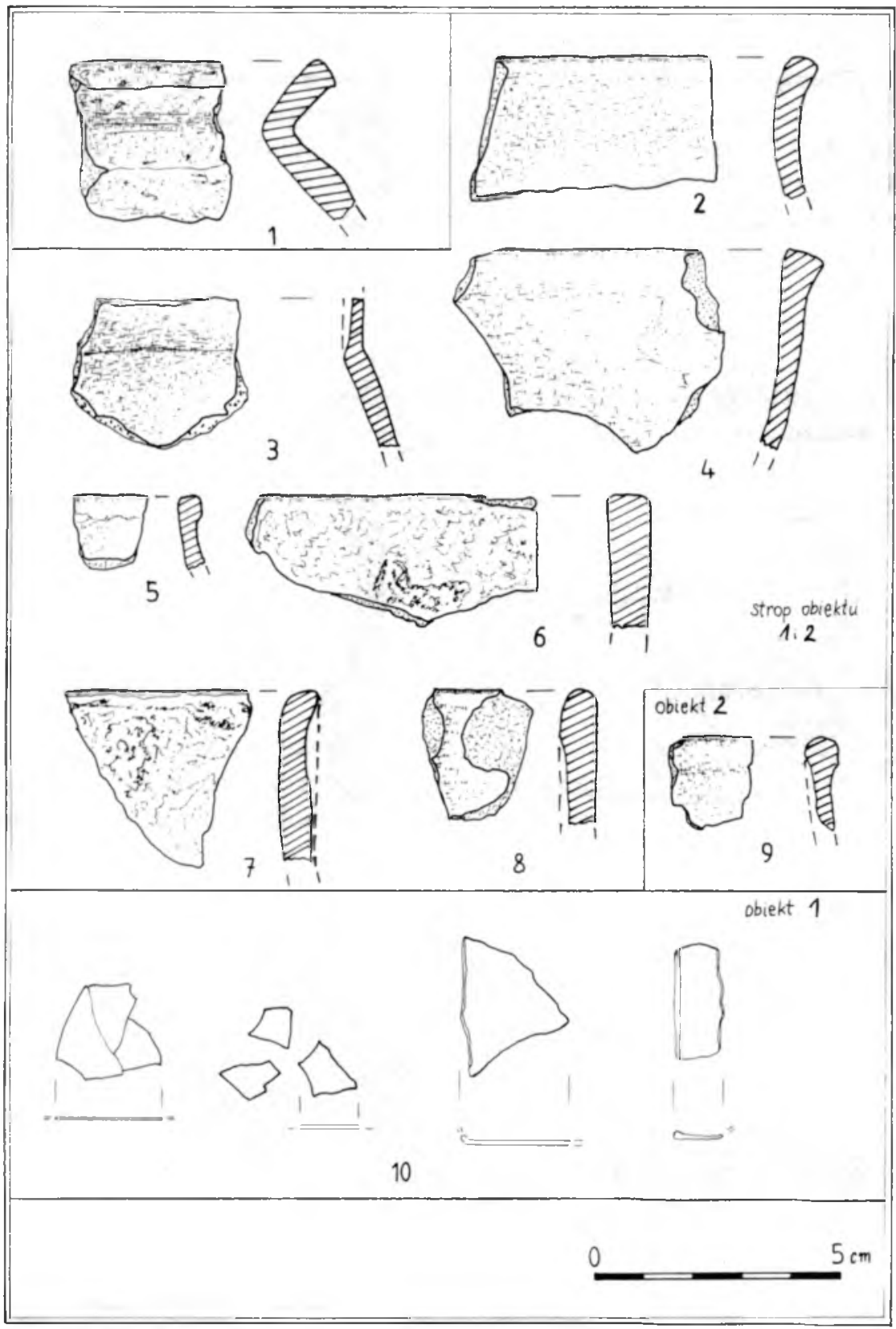

Ryc. 7. Nowy Kraków, gm. Darłowo, stan. 1. Wybór ceramiki z kurhanu nr 2:1 - nasyp; 2-8 strop obiektu 1 i $2 ; 9$ - obiekt nr 2;10 - fragmenty blaszki z obiektu nr 1

Abb. 7. Nowy Kraków, Gem. Darłowo, Fst. 1. Keramikauswahl aus Hügel 2. 1 - Aufschüttung; 2-8 - obere Schicht der Befunde 1 und 2;9 - Befund 2;10 - Blechfragment aus Befund 1 


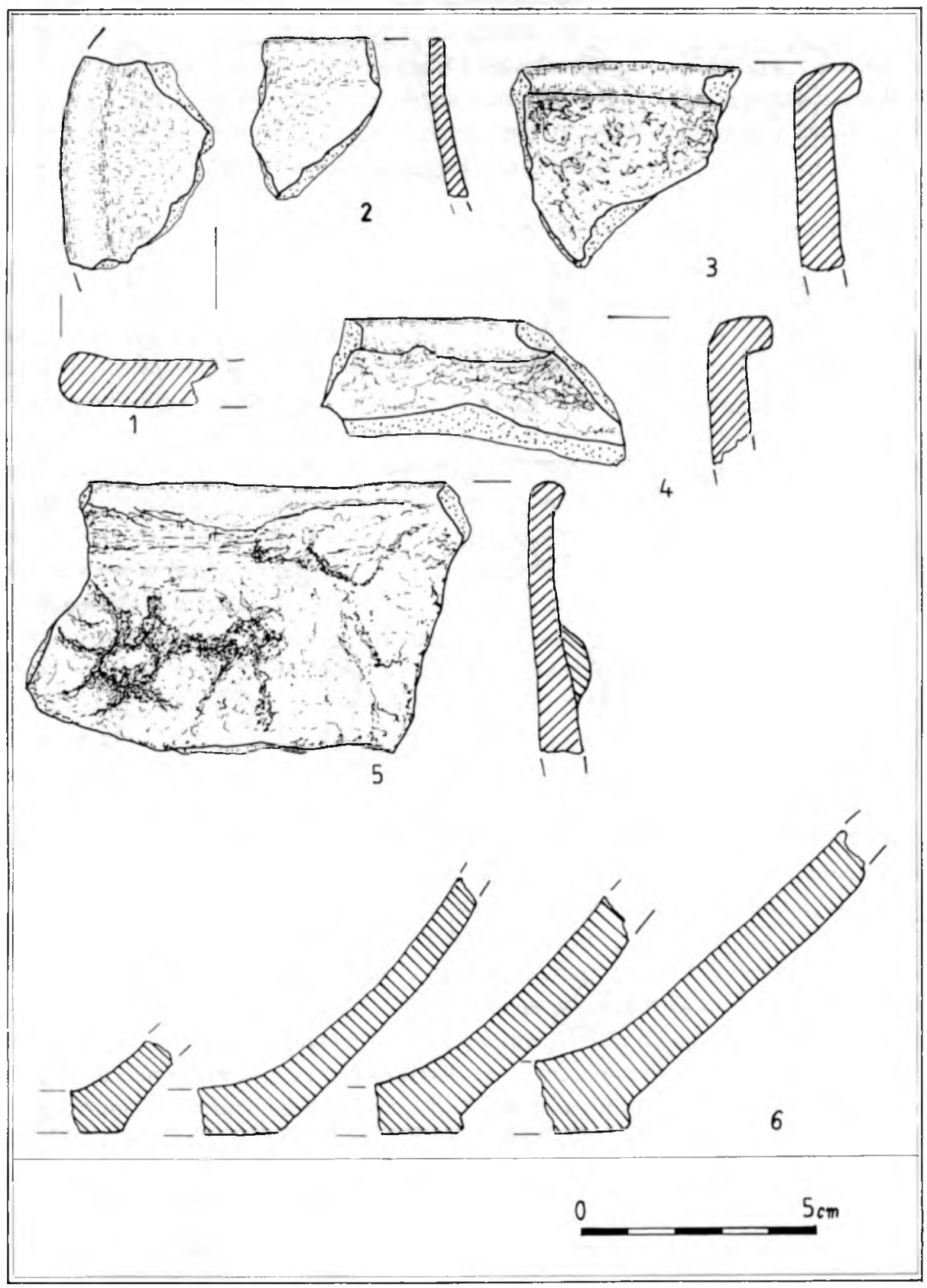

Ryc. 8. Nowy Kraków, gm. Darłowo, stan. 1. Wybór ceramiki z kurhanu nr 2, obiekt nr 1 Abb. 8. Nowy Kraków, Gem. Darłowo, Fst. 1. Keramikauswahl aus Hügel 2, Befund 1 
$\mathrm{Z}$ racji stosunkowo dużej odległości między kurhanem $\mathrm{nr} 1$, badanym przez H.J. Eggersa, i kurhanem nr $2(120 \mathrm{~m})$ trudno wysuwać wnioski na temat związku tych obiektów osadowych z odkrytymi w 1937 r. grobami ciałopalnymi, pochodzącymi mniej więcej z tego samego czasu.

Ceramika znaleziona w nasypie potwierdziła datowanie cmentarzyska kurhanowego na wczesny okres rzymski, ustalone wcześniej przez H.J. Eggersa. W świetle dotychczasowych badań jest to, po Gronowie ${ }^{19}$ i Nowym Łowiczu ${ }^{20}$, trzecie znane do tej pory cmentarzysko z kurhanami o wyłącznie ziemnych nasypach kultury wielbarskiej z terenu bylego województwa koszalińskiego (Pomorza Środkowego).

Odkryte w 1937 i 1991 r. obiekty wskazuja, że na tym dość rozległym terenie, zajmowanym obecnie przez cmentarzysko kurhanowe, istniała osada halsztacka w jego części południowo-zachodniej oraz cmentarzysko użytkowane od młodszej epoki brązu do okresu halsztackiego, zlokalizowane w części północno-wschodniej obecnego pola kurhanowego. We wczesnym okresie rzymskim wykorzystano ten teren na cmentarzysko kurhanowe. Zbyt skromny jednak zakres badan ogranicza nasze możliwości interpretacyjne.

\section{BIBLIOGRAFIA}

\section{A. WYKAZ SKRÓTÓW}
AB - „Archaeologia Baltica”, Łódź;
KZM - „Koszalińskie Zeszyty Muzealne”, Koszalin;
MZP - „Materialy Zachodniopomorskie”, Szczecin.

\section{B. LITERATURA}

Cnotliwy E., Kamiński R., Rogosz R.

1975 Osada z wczesnego i środkowego okresu lateńskiego w Pomianowie, b. pow. Bialogard, stanowisko $16, \mathrm{KZM}$ t. 5, s. 37-85.

Garczyński W

1956 Kurhan z okresu rzymskiego z Nowego Krakowa w pow. sławienskim [Zus.: Das Hügelgrab aus der Römischen Kaiserzeit in Nowy Kraków, Kreis Stawno], MPZ t. II, s. 113-123.

Hahula K.

1988 Nowy Lowicz - cmentarzysko kurhanowe z okresu wplywów rzymskich [Zus.: Nowy Lowicz Hügelgräberfeld aus der Zeit der Römischen Einflüsse], KZM t. 18, s. 37-54.

Informator

1997 „Informator Archeologiczny. Badania rok 1991”, s. 72 (K. Hahuła)

Kleist D. von

1955 Die urgeschichtlichen Funde des Kreises Schlawe, Hamburg.

\footnotetext{
${ }^{19}$ Wołągiewicz 1974, s. 141 .

${ }^{20} \mathrm{H}$ a huła 1988 , s. 50 .
} 
Kostrzewski J.

1966 Pradzieje Pomorza [Sum.: Prehistory of Pomerania]. Wrocław-Warszawa-Kraków.

Kunkel O.

1939 Urgeschichte, (w:) Erwerbungs- und Forschungsbericht, Stettin, s. 11-68.

Schindler R.

1940 Die Besiedlungsgeschichte der Goten und Gepiden in unteren Weischselraum auf der Tongefässe, Leipzig.

Skrzypek I.

1976 Ratownicze badania wykopaliskowe w Glomsku, gm. Zakrzewo, woj. Piła w 1971 roku, KZM t. 6, s. $75-101$

1982 Archeologiczne badania ratownicze w Koszalinie na stanowisku 12, KZM t. 12, s. 13-28.

1987 Zespól osadniczy ludności kultury pomorskiej w Klukowie, stanowisko 2, gm. Zlotów, woj. Pila, cz. II - osada, KZM t. 17, s. 3-46.

1998 Miscellanea archeologiczne, KZM t. 22, s. 261-293.

Strzyżewski Cz., Żurawski Z.

1973 Wstępne sprawozdanie z badań wykopaliskowych na stanowisku 3 w Dzierżęcinie, pow. Stawno w 1972 r., KZM t. 3, s. 90-101.

Walenta K.

1981 Obrzqdek pogrzebowy na Pomorzu w okresie późnolateńskim i rzymskim [Sum.: Funeral rites in the Late-Laten and Roman periods in Pomerania], AB vol. V, Polonia 80/81.

Wołagiewicz R.

1974 Zagadnienie stylu wczesnorzymskiego w kulturze wielbarskiej, (w:) Studia Archaeologica Pomeranica [Zus.: Zur Frage der Stilwandlung der frühen Römischen Kaiserzeit in der Wielbark Kultur], Koszalin, s. 129-152.

1993 Ceramika kultury wielbarskiej między Baltykiem a Morzem Czarnym [Zus.: Die Tongefäße der Wielbark-Kultur in Raum zwischen Ostsee und Schwarzen Meer], Szczecin.

\section{AUSGRABUNGEN UND INVENTARISIERUNGSARBEITEN IN NOWY KRAKÓW, GEM. DAREOWO, FST. 1.}

\section{Zusammenfassung}

Der Fundplatz wurde archäologisch erstmals im Jahr 1937 erforscht, als H. J. Eggers teilweise einen Grabhügel untersuchte, von welchem vorher Sand abgetragen worden war. Er bestimmte den Hügel als frühkaiserzeitlich, hingegen die unter dem Hügel befimdlichen Befunde als jüngerbronze- und hallstattzeitlich. Der Fundplatz besteht aus zwei Zonen, in denen Grabhügel auftreten: Eine nordöstliche, gegenwärtig mit jungem Buchen-Fichten-Wald bestandene und eine südwestliche, wo vor nicht zu langer Zeit junge Kiefern gesetzt wurden. Es handelt sich um das Gebiet des Forstes Czarnolas, Abteilung Nowy Kraków, Waldstück 180-181, Forstamt Sławno, Gemeinde Darłowo, Wojewodschaft Zachodniopomorskie. Im Zuge der Inventarisationsarbeiten im Jahr 1991 wurden 25 Grabhügel aus Sandaufschüttung lokalisiert, jedoch sind die Sichtverhältnisse aufgrund des Baumbestandes ungünstig und ihre Zahl kann sich noch verăndern. Für eine Untersuchung wurde ein mittelgroßer Grabhügel ausgewählt, der zu zwei Vierteln ausgegraben wurde. Im Zentrum, in der Aufschüttungsschicht, fand man ein unbestimmbares Eisenfragment und Keramikbruchstücke, darunter ein Randfragment eines frührömischen Gefäßes. Auf Höhe des anstehenden Sandes wurden große Befunde mit Brandspuren, Rotlehm- und Holzkohlestücken sowie in die Hallstattzeit datierende Keramik freigelegt. Die Untersuchungen bestätigten die Datierung des Hügelgräberfeldes in die frührömische Kaiserzeit, welches sich über Siedlungsbefunden der Pommerschen Kultur befindet. 